\title{
Chronic Hepatitis C
}

\author{
Jae Young Jang* and Raymond T. Chung ${ }^{\dagger}$
}

*Institute for Digestive Research, Digestive Disease Center, Department of Internal Medicine, Soonchunhyang University College of Medicine, Seoul, Korea, 'Gastrointestinal Unit, Department of Medicine, Massachusetts General Hospital, Harvard Medical School, Boston, MA, USA

The goal of antiviral therapy for patients with chronic hepatitis $\mathrm{C}$ virus $(\mathrm{HCV})$ infection is to attain a sustained virologic response (SVR), which is defined as undetectable serum HCV-RNA levels at 6 months after the cessation of treatment. Major improvements in antiviral therapy for chronic hepatitis $\mathrm{C}$ have occurred in the past decade. The addition of ribavirin to interferon-alfa therapy and the introduction of pegylated interferon (PEG-IFN) have substantially improved SVR rates in patients with chronic hepatitis $\mathrm{C}$. The optimization of HCV therapy with PEG-IFN and ribavirin continues to evolve. Studies are ongoing that use viral kinetics to tailor therapy to an individual's antiviral response and determine the ideal length of treatment to maximize the chance of SVR. Improved SVR can be achieved with new specific inhibitors that target the HCV NS3/4A protease and the NS5B polymerase. Several long-term follow-up studies have shown that SVR, when achieved, is associated with a very low risk of virologic relapse. Furthermore, antiviral therapy can reduce the morbidity and mortality rates associated with chronic hepatitis $C$ by reducing fibrosis progression, the incidence of cirrhosis, and hepatocellular carcinoma. (Gut Liver 2011;5:117-132)

Key Words: Chronic hepatitis C; Virology; Therapeutics

\section{INTRODUCTION}

Hepatitis C virus (HCV) infects 170 million people worldwide. ${ }^{1}$ It causes severe liver disease, ranging from chronic hepatitis to cirrhosis and even hepatocellular carcinoma. ${ }^{2} \mathrm{HCV}$-related liver diseases are responsible for 12,000 deaths annually in the United States. In contrast to most other viral infections, the hallmark of HCV viral infection is that most patients develop chronic infection after viral exposure. ${ }^{3}$ Unfortunately, no effective vaccine is available for HCV. The current treatment for chronic HCV infection is the combination of peginterferon (IFN)- $\alpha$ and a nucleoside analogue, ribavirin. ${ }^{4}$ This article reviews our current understanding of chronic hepatitis C infection.

\section{EPIDEMIOLOGY}

HCV is an RNA virus known to infect humans and chimpanzees, causing a similar disease in these 2 species. HCV is the most common cause of transfusion-related hepatitis and is one of the leading causes of end-stage liver disease requiring liver transplantation in the United States. HCV is transmitted most efficiently by parenteral means, particularly with large or repeated exposure to infected blood products, upon transplantation of infected tissue or organ grafts, and between intravenous drug users (IVDU). Less frequently, HCV can be transmitted by mucosal exposure to blood or serum-derived fluids through perinatal or sexual means. ${ }^{5}$

In 2004, the Global Burden of Hepatitis C Working Group, a consultant to the World Health Organization (WHO), estimated the global prevalence of HCV to be slightly lower than $2.2 \%$, or 130 million individuals. The lowest HCV prevalence, between $0.01 \%$ and $0.1 \%$, is in the United Kingdom and Scandinavia, while the highest prevalence, between $15 \%$ and $20 \%$, is in Egypt (Fig. 1). ${ }^{6}$ Hepatitis C is estimated to be the cause of $27 \%$ of cirrhosis and 25\% of hepatocellular carcinoma (HCC) cases worldwide. ${ }^{7}$

Prior to the implementation of universal screening of blood donors in the United States in 1992, the predominant mode of HCV transmission was exposure to infected blood and blood products. At present, IVDU and high-risk sexual exposures account for most HCV transmission. ${ }^{6}$ Enhanced screening of blood products has led to a decline in the estimated incidence of acute hepatitis C from 180,000 in the mid-1980s to an estimated 19,000 in 2006. HCV is estimated to cause 8,000 to 10,000 deaths per year related to liver complications and HCC. ${ }^{6}$

The WHO Western Pacific region has an estimated HCV

Correspondence to: Raymond T. Chung

Gastrointestinal Unit, Massachusetts General Hospital, Warren 1007, Boston, MA 02114, USA

Tel: +1-617-724-7562, Fax: +1-617-643-0446, E-mail: rtchung@partners.org

Received on February 9, 2011. Accepted on March 21, 2011.

pISSN 1976-2283 eISSN 2005-1212 DOI: 10.5009/gnl.2011.5.2.117

@ This is an Open Access article distributed under the terms of the Creative Commons Attribution Non-Commercial License (http://creativecommons.org/licenses/by-nc/3.0) which permits unrestricted non-commercial use, distribution, and reproduction in any medium, provided the original work is properly cited. 


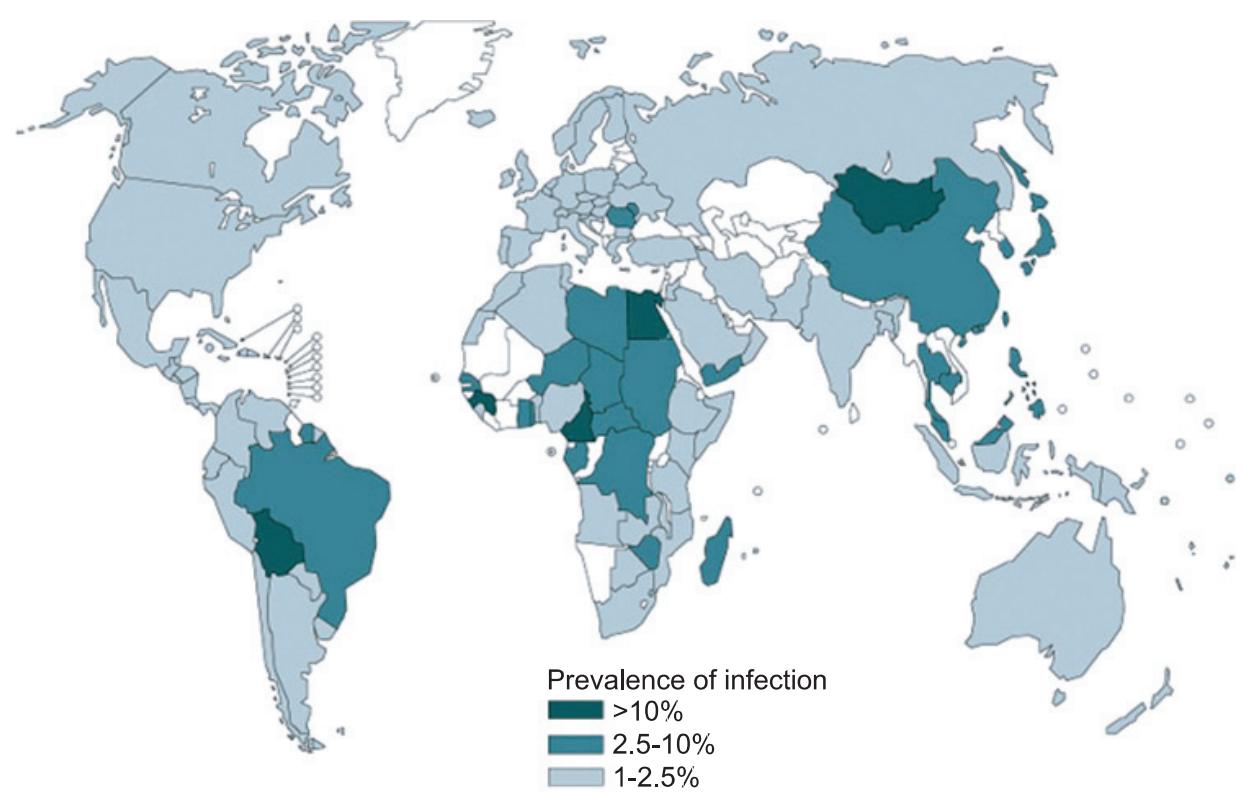

Fig. 1. Geographic distribution of hepatitis C infection worldwide, 2007 (Data from International Travel and Health [Internet]. Geneva: World Health Organization; 2007 [cited 2009 Mar 11]. Available from: http://www.who.int/ith/maps/hepatitisc2007.jpg).

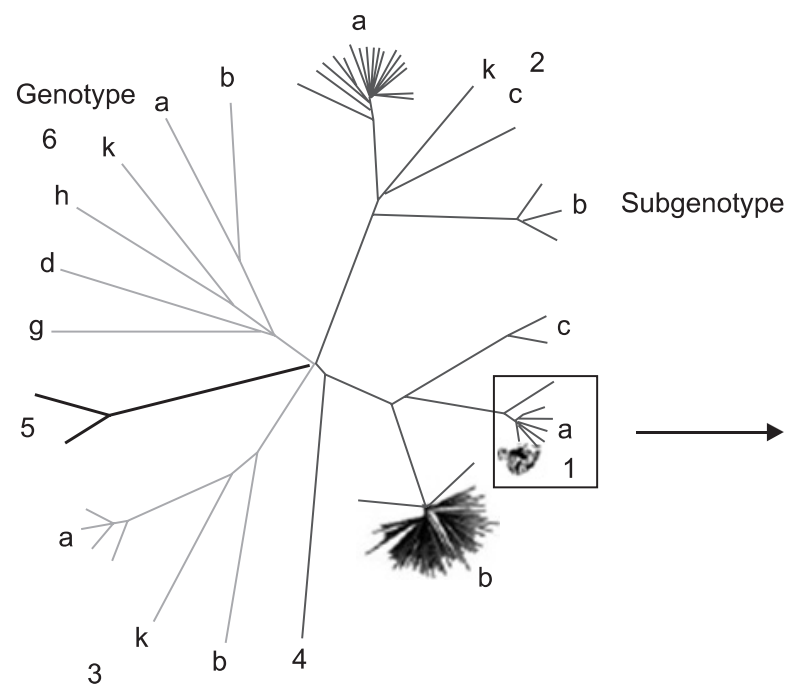

prevalence of 3.9\%, or 62.2 million people. Approximately 3.2\% of China's population, or 38 million individuals, were found to have HCV in a national epidemiologic survey performed between 1992 and 1995. The primary means of transmission in China is IVDU, and HCV incidence in the injection drug user (IDU) cohort is as high as 3.6 cases per 100 person-years. ${ }^{8}$ In Japan, the estimated HCV prevalence is $2 \%$, or 2 million people. ${ }^{9}$ The prevalence is directly proportional to age, with the highest rate of $7 \%$ seen in individuals older than 70 years. ${ }^{10}$ Modes of transmission include blood transfusions, IDU, and unsafe needle use in medical practice prior to 1980 . Hepatitis C is the major etiological factor for HCC in Japan, where HBV is not endemic. ${ }^{11}$

\section{GENOTYPES}

There are $6 \mathrm{HCV}$ genotypes (genotypes 1 to 6), many subtypes (a, b, c, etc.), and approximately 100 different strains (1,
Fig. 2. Hepatitis C virus (HCV) sequences have been classified into six major genotypes with approximately $65 \%$ sequence identity. Within each genotype, sequences are further classified into subtypes with $78 \%$ sequence identity. Different isolates within the same subtype share $91 \%$ to $99 \%$ sequence identity. Within Isolate a host, HCV particles circulate as a population of very closely related, but not identical, variants referred to as quasispecies. Genotypes are denoted by numbers (1-6), and subgenotypes are denoted by lower case letters (Adapted from Fishman SL, et al. Infect Genet Evol 2009;9:11581167). ${ }^{12}$

2, 3, and so forth) based on the sequence heterogeneity of the HCV genome (Fig. 2). ${ }^{12}$ Genotypes 1 to 3 are widely distributed globally, with genotypes $1 \mathrm{a}$ and $1 \mathrm{~b}$ accounting for 60\% of infections worldwide. Genotype 1a is predominantly located in northern Europe and North America, whereas genotype $1 \mathrm{~b}$ is predominantly found in southern and eastern Europe and Japan. Genotype 2 is less common than genotype 1 and is found more frequently in Europe than in North America. Genotype 3 is endemic to South-East Asia, and genotype 4 is characteristic of the Middle East, Egypt, and central Africa. Genotype 5 is almost exclusively found in South Africa, and genotype 6 is primarily distributed in Asia. ${ }^{5,13-15}$

The impact of the viral genotype on the pathogenesis of liver disease remains a subject of controversy, but the influence of the genotype on the response to interferon-based therapy is established. Genotype 1 is generally associated with a poorer response to therapy, whereas genotypes 2 and 3 have more fa- 
vorable responses. Genotype 4 seems to have an intermediate response. $^{15,16}$

\section{VIROLOGY OF HEPATITIS C}

HCV was first isolated in $1989 .{ }^{17}$ It is a plus-stranded RNA virus with a genome size of $9.6 \mathrm{~kb}$ (Fig. 3). ${ }^{1}$ The virus is classified as the distinct genus Hepacivirus in the family Flaviviridae. ${ }^{18}$ HCV replicates through a negative-strand RNA intermediate without evidence of DNA formation. Although viral RNA has been detected in the serum, spleen, and lymph nodes of infected patients, most in vivo and in vitro evidence supports the notion that HCV is a hepatotropic virus and that viral RNA replicates exclusively in human hepatocytes.

HCV encodes a single polyprotein of 3011 amino acids. Translation occurs through cap-independent and internal ribosome entry site-mediated mechanisms. The HCV internal ribosome entry site translation system requires the formation of a protein complex composed primarily of eukaryotic initiation factors 2 and $3 .^{19}$ This protein is subsequently processed into at least 10 functional proteins to support viral replication and production.

A host signal peptidase is responsible for cleavage between $\mathrm{C} /$ $\mathrm{E} 1, \mathrm{E} 1 / \mathrm{E} 2, \mathrm{E} 2 / \mathrm{p} 7$, and p7/NS2. Viral NS2, however, is responsible for cleavage of NS2/3, and the NS3 protease is responsible for downstream protein processing. ${ }^{20}$

The HCV core protein is a highly conserved viral capsid protein. In addition to its role in viral particle assembly, the core protein seems to exert multiple biologic functions on host cells, including gene transcriptional regulation, ${ }^{21}$ apoptosis, ${ }^{22,23}$ alteration of IFN signaling, ${ }^{24,25}$ cell transformation, ${ }^{26,27}$ and interference with lipid metabolism. ${ }^{28}$ Many of these biologic effects of the core protein are thought to provide a survival advantage to the virus.

The E1/E2 proteins are glycoproteins on the viral surface. These envelope proteins have attracted great interest because of their potential use in the development of an HCV vaccine. ${ }^{29,30}$ The E2 region is known to be hypervariable, however, which creates significant problems for the generation of effective neutralizing antibodies. Recent experiments have demonstrated that E1/E2 proteins can form pseudoviral particles and that these particles are capable of eliciting antibody responses. ${ }^{30-32}$ Interestingly, it has also been reported that E2 can interact with the cellular protein PKR, a key signaling molecule in IFN-induced antiviral pathways. ${ }^{33}$

The p7 protein is located between the structural and nonstructural proteins. This protein is embedded in the cellular membrane and functions as an ion channel. In a chimpanzee study, a virus with $\mathrm{p} 7$ mutations could not establish infection, ${ }^{34}$ indicating the essential role of this protein in the viral life cycle.

The viral NS2 protein is a serine protease responsible for the cleavage of NS2/3 and is an integral membrane protein. NS2 can be phosphorylated by protein kinase CK2 and is involved in the modulation of cell apoptosis and transcription. ${ }^{35} \mathrm{NS} 3 / 4 \mathrm{~A}$ is responsible for most of the nonstructural protein processing. Recently, NS3/4A was implicated in the modulation of host cellular functions. It was reported that HCV NS3 promoted caspase8-mediated apoptosis. ${ }^{36}$ Interestingly, NS3/4 has been shown to interfere with the host innate immune system. ${ }^{37,38}$ NS5A is a membrane-associated protein. It has a structural basis for interacting with other proteins and viral RNAs. ${ }^{39-41}$ NS5A is phosphorylated by cellular serine kinases, including MEK1, MKK6, AKT, p70S6K, and cAMP-dependent protein kinase A-a. ${ }^{42-46}$ In addition, NS5A appears to have the capacity to modulate multiple cellular functions, including cell transformation, transcriptional regulation, and apoptosis. NS5A also interacts with other cellular factors to result in the suppression of IFN-induced antiviral efficacy. ${ }^{47}$

NS5B is an RNA-dependent RNA polymerase responsible for viral RNA replication. The protein's structure bears the typical "right hand" polymerase domain. ${ }^{48-50}$ The precise molecular process of NS5B-mediated RNA replication remains to be defined, but replication complexes composed of multiple proteins appear to be involved..$^{51,52}$ Interestingly, a cellular replication cofactor, cyclophilin A, can enhance the RNA binding activity of NS5B, and cyclosporine exhibits anti-HCV activity through this mechanism. $^{53}$

Although the molecular details underlying the entry of HCV into the host cell are unknown, CD81 seems to be a key receptor component mediating viral entry. ${ }^{54,55}$ CD81 alone is not sufficient to convert nonpermissive cells to allow HCV entry, however, as demonstrated in cell culture and in CD81transgenic mice; such animals expressing human CD81 were not susceptible to HCV infection. ${ }^{56,57}$ It is believed that other cofactors in association with CD81 act to coordinate the entry of HCV into the host cells. ${ }^{58}$ One viral protein that is likely essen-

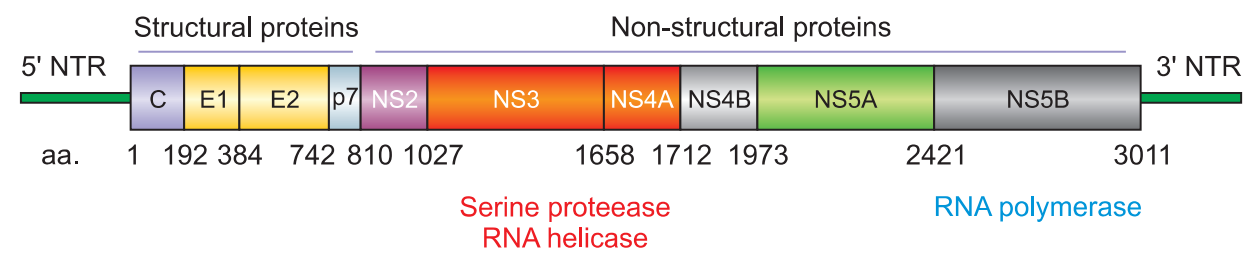

Fig. 3. Genomic structure of hepatitis C virus (HCV). HCV is a plus-stranded RNA virus. The total viral protein is 3011 amino acids (aa) in length. It consists of structural and nonstructural proteins processed from a single polyprotein by host and viral proteases. 
tial for host cell binding is E2, which has been demonstrated to bind CD81 both in vitro and in vivo. ${ }^{59}$ Other potential receptors include low-density lipoprotein, negatively charged glycosaminoglycans, and human scavenger receptor class B type $1 .^{60,61} \mathrm{An}$ additional host cell molecule that was recently identified to be important for HCV entry is the tight junction protein Claudin-1 (CLDN1). The expression of CLDN1 in several nonpermissive cell lines allowed viral entry, and siRNA silencing of CLDN1 expression in permissive hepatoma cells reduced HCV infection and mutagenesis. Furthermore, antibody blocking studies with tagged versions of CLDN1 demonstrated that the first extracellular loop of CLDN1 (EC1) is an essential coreceptor during one or more stages of the HCV entry process. ${ }^{62}$ Recent studies have also identified occludin (OCLN), an integral tight junction (TJ) protein, as another key factor for HCV entry. ${ }^{63}$

The hallmark of HCV infection is the establishment of persistent viral infection. The mechanisms underlying this remain unclear. Many lines of evidence appear to support the idea that HCV infection is noncytopathic. Several studies, including histologic examination of liver biopsies, have shown that many HCV carriers have high titer virus expression and normal liver enzyme levels but little or no liver damage. ${ }^{64-68}$ The course of varying degrees of hepatitis, whether to resolution or chronic infection, seems to be controlled at the level of the host immune response to virus-infected hepatocytes. It must be noted, however, that the majority of the data examining the relationship between host immune response and disease progression have been derived from patient populations with chronic infection, in which cases the virus and host hepatocytes had coevolved for some time. It remains to be determined whether HCV can exert cytopathic effects on naive hepatocytes during the initial viral exposure. Understanding how HCV establishes persistent infection is crucial for future strategies to control this disease.

Over the past decade, many mechanisms by which HCV may establish chronicity have been proposed. ${ }^{3,69}$ These mechanisms include virus-encoded anti-host immune strategies, virus-induced immunologic tolerance, viral escape mutations, molecular mimicry, and decreased effectiveness of antiviral cytokines. In recent years, experimental evidence has suggested that virusencoded, anti-host strategies play an essential role in the establishment of persistent viral infection (Fig. 4). ${ }^{70}$ All mammalian nucleated cells have an innate capacity to respond to a viral infection through the production of type I IFNs or other inflammatory cytokines. ${ }^{71-73}$ This defense system has been extensively studied, leading to a wealth of knowledge on the molecular basis of this innate immune system.

\section{FACTORS IMPACTING TREATMENT RESPONSE}

The viral factors that have been demonstrated to play a role in the response to IFN-based therapy include genotype and viral load. Patients with low baseline viremia (below 400,000 IU/

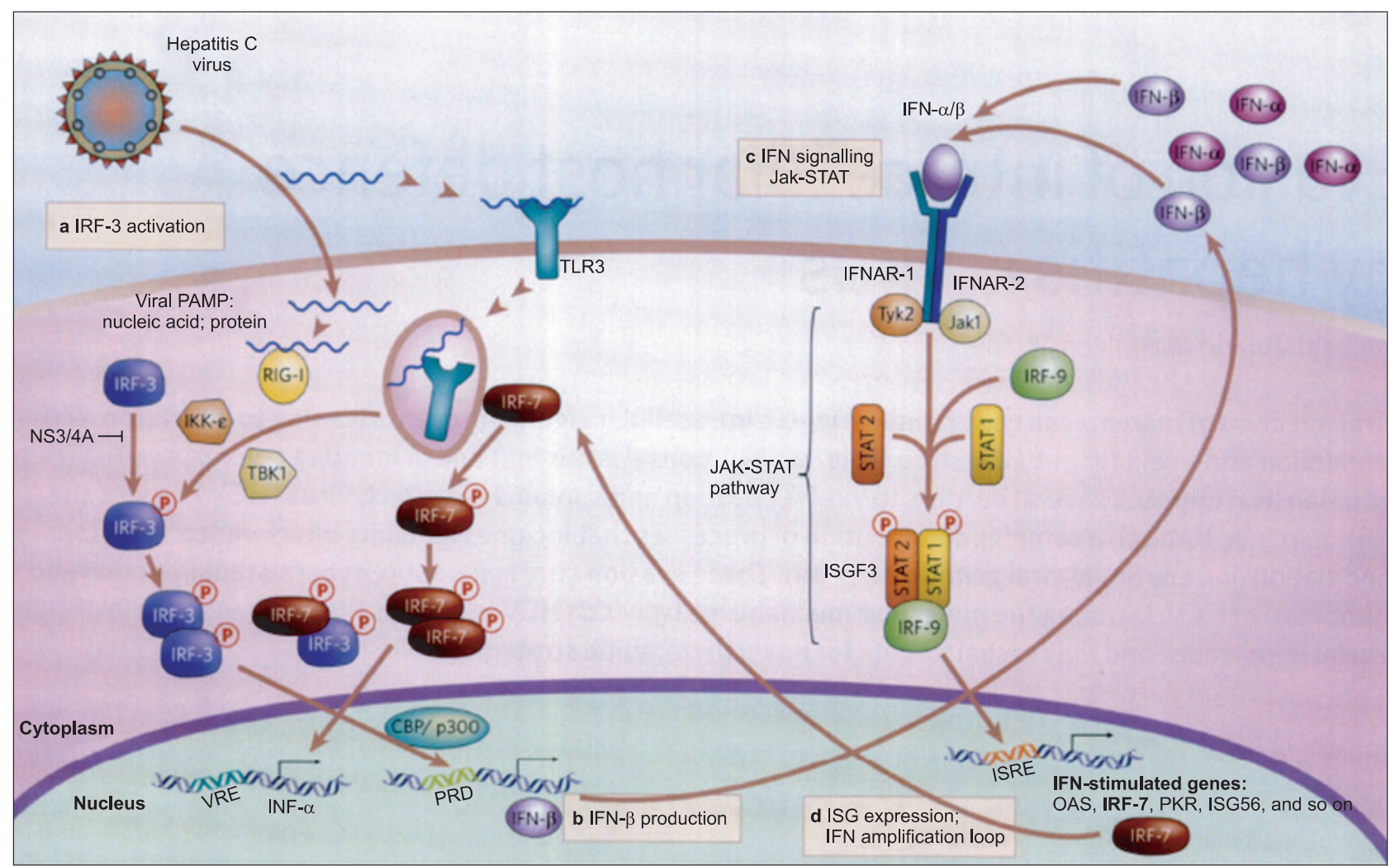

Fig. 4. Molecular processes that signal the host response to hepatitis C virus infection (Adapted from Gale M Jr, et al. Nature 2005;436:939-945). ${ }^{70}$ 
$\mathrm{mL}$ ) are more likely to respond to therapy than patients with high baseline viremia. ${ }^{74}$ Numerous host factors can influence treatment outcomes, including age, sex, race, weight, liver fibrosis, steatosis, and insulin resistance. Unfortunately, most host factors cannot be altered (age, sex, race, fibrosis), and those that can be altered may not be associated with an improved sustained viral response (SVR). A recently uncovered example of the influence of host factors on SVR is insulin resistance, the presence of which prior to treatment leads to a dramatic reduction in SVR rates. ${ }^{75}$ Insulin resistance seems to be involved in decreased sensitivity to interferon and could block intracellular interferon signaling. Recently, a new and powerful host variable was found using genome-wide association studies. A genetic polymorphism near the IL-28B gene region, which encodes for interferon lambda, has been closely linked to the IFN response. Patients with the CC allele have a very high SVR compared to those with a T-containing allele (Fig. 5). ${ }^{76}$ The IL-28B polymorphism influences virologic responses and relapse rates and has become the most powerful pretreatment predictor of SVR. ${ }^{77}$ In fact, with the era of direct antiviral therapies close at hand, testing for this polymorphism will be critical in determining who should be treated immediately and who should wait for improved treatment regimens. Patients who have the favorably responding CC IL-28B genotype have a high likelihood of attaining SVR and, in the absence of other concerns regarding their candidacy for therapy, should be considered candidates for standard PEG-IFN and RBV therapy. In contrast, patients with the non-CC IL-28B genotype, especially if other markers of poor response are present (e.g., high viral load, insulin resistance, and African American ancestry), are unlikely to achieve SVR and should consider waiting for improved response rates with direct antivirals. $^{78,79}$

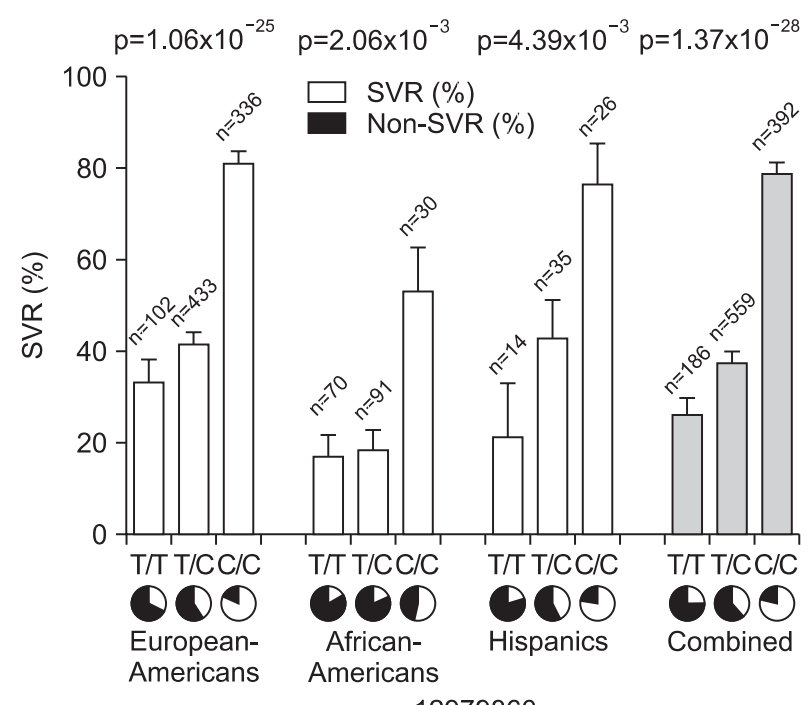

rs12979860

Fig. 5. Percentage of sustained virologic response (SVR) by rs12979860 genotypes (Adapted from Ge D, et al. Nature 2009; $461: 399-401)^{76}$

\section{TREATMENT CANDIDATES}

Antiviral therapy for chronic hepatitis $\mathrm{C}$ is currently recommended for patients who 1) are older than 18 years, 2) have positive findings for HCV antibodies and serum HCV RNA, 3) have liver biopsy findings consistent with a diagnosis of chronic hepatitis, although a biopsy is not essential, and 4) have no contraindications for treatment. PEG-IFN and RBV cannot be used in patients with decompensated cirrhosis, severe depression, or cardiopulmonary disease.

\section{DEFINITION OF VIRAL RESPONSE PATTERNS AND AS- SOCIATED SVR}

The monitoring of on-treatment viral responses has become a vital aspect of treatment regimens and allows one to predict the treatment response, to consider therapy adjustments, and to develop stopping rules governing cessation of therapy. A clear relationship has been established between the time to viral negativity and SVR. Patients who initially achieve serum viral negativity by week 4 (RVR) or week 12 (cEVR) have 91\% and $60 \%$ to $72 \%$ SVR rates, respectively, following 48 weeks of therapy. Patients who decrease their viral loads by 2 logs following 12 weeks of treatment and who achieve viral negativity by week 24 are referred to as slow responders and have much lower rates of SVR (35\% to 45\%). Patients who do not achieve a 2-log reduction by week 12 or viral negativity by week 24 have only a $2 \%$ chance of achieving SVR with therapy, and treatments are therefore typically stopped.$^{80}$ On-treatment viral response definitions related to week-4, -12 , and -24 HCV RNA determinations and their relationships to SVR are shown below (Figs 6 and 7):

- Rapid virological response (RVR): HCV RNA negative (<50 $\mathrm{IU} / \mathrm{mL}$ ) after 4 weeks of therapy

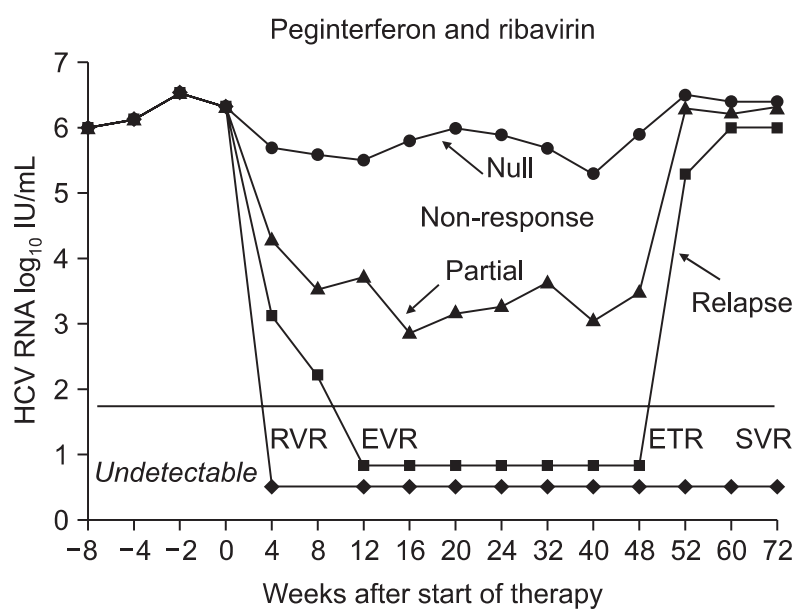

Fig. 6. Graphic display of virological responses (Adapted from AASLD Practice Guideline: Diagnosis, Management, and Treatment of Hepatitis C. An Update). ${ }^{149}$ 
- Early virological response (EVR): viral response at 12 weeks, subdivided into:

- Partial EVR (pEVR): HCV RNA >2-log drop, but still detectable at week 12

- Complete EVR (cEVR): no RVR, but HCV RNA <50 IU/mL at week 12

- Nonresponse: persistent or inadequate reduction in HCV RNA during therapy, subdivided into:

- Null response: either <1-log decrease in HCV RNA at week 4 or $<2-\log$ decrease in HCV RNA by week 12

- Partial response: greater than a 2-log decrease by week 12 , but continued viral positivity at week 24

Partial and null responses are associated with $<5 \%$ likelihood for SVR and have been accepted as a general stopping rule.

\section{TREATMENT}

\section{Goals of treatment}

The primary goal of chronic HCV treatment is a SVR, which is defined as undetectable serum HCV RNA levels 6 months after treatment cessation. For patients to achieve this goal, however, three independent milestones must be sequentially achieved. The first of these is that the patient must achieve a virologic response and have undetectable HCV RNA levels during treatment. It is fairly evident but rarely stated that patients without a virologic response cannot possibly achieve SVR. The second step is that the patient must maintain this response by maintaining undetectable HCV RNA levels throughout the duration of therapy. With few exceptions, patients who experience breakthrough and become HCV RNA-positive during treatment do not achieve SVR. The final step for SVR is that the patient must not relapse following treatment.

\section{Response-guided therapy}

The current effective treatment for chronic HCV infection is

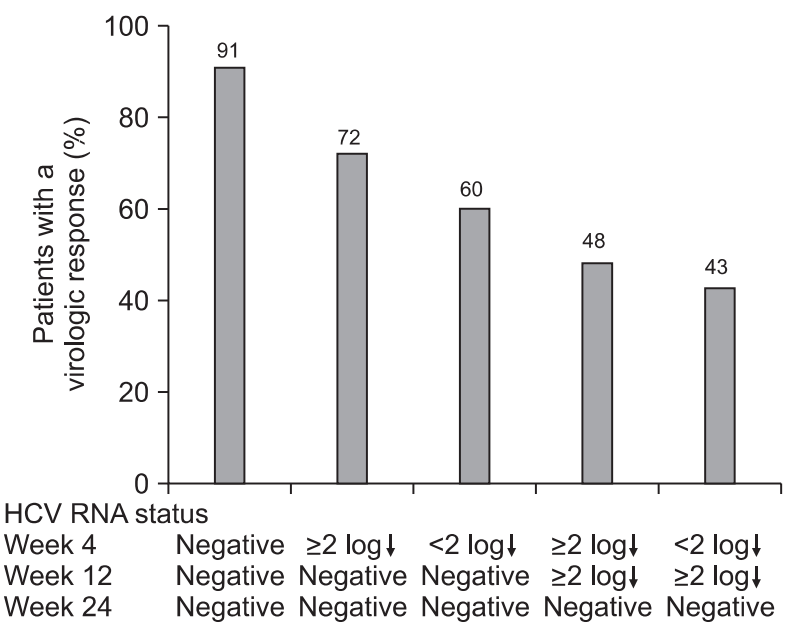

Fig. 7. Rates of viral clearance predict sustained virologic response in patients with PEG-RBV treatment (Adapted from Ferenci P, et al. J Hepatol 2005;43:425-433). ${ }^{80}$ a combination of peginterferon and ribavirin. ${ }^{81,82}$ The term EVR refers to a 2-log decline in HCV RNA levels from the pretreatment baseline or undetectable HCV RNA levels within 12 weeks of treatment initiation..$^{81,83,84}$ Approximately 80\% of patients with genotype 1 and virtually all patients with genotypes 2 or 3 achieve an EVR. ${ }^{80,81,83-86}$ Patients without EVR rarely if ever achieve SVR. ${ }^{80,81,83,84,86}$ These patients are referred to as having a null response. ${ }^{87}$ At the Second National Institutes of Health Consensus Development Conference on the Management of HCV, it was recommended that all patients infected with genotype 1 should undergo HCV RNA testing at baseline and at week $12 .^{83,84}$ Patients without EVR (a null response) should cease treatment because they cannot achieve SVR. It was further recommended that all genotype 1-infected patients showing EVR should continue treatment for 48 weeks and that all patients infected with genotypes 2 and 3 should simply be treated for 24 weeks. ${ }^{81,83,84}$

Defining the time when HCV RNA first becomes undetectable in the patient is critically important in the management of HCV treatment because this measurement is directly related to the likelihood of SVR. ${ }^{80}$ Patients in whom HCV RNA is undetectable within 4 weeks of initiating treatment are referred to as having a RVR. Approximately 15\% of patients infected with genotype 1 and $66 \%$ of patients infected with genotypes 2 and 3 achieve RVR. ${ }^{80,85}$ These patients are exquisitely sensitive to treatment; they achieve SVR at a rate of 90\% regardless of their genotype and the type of therapy they receive. ${ }^{80,85}$ In a retrospective analysis of a large clinical trial database, patients infected with genotype 1 and showing RVR had a 90\% likelihood of achieving SVR whether treated with peginterferon and full-dose ribavirin, a lower dose of ribavirin, standard interferon

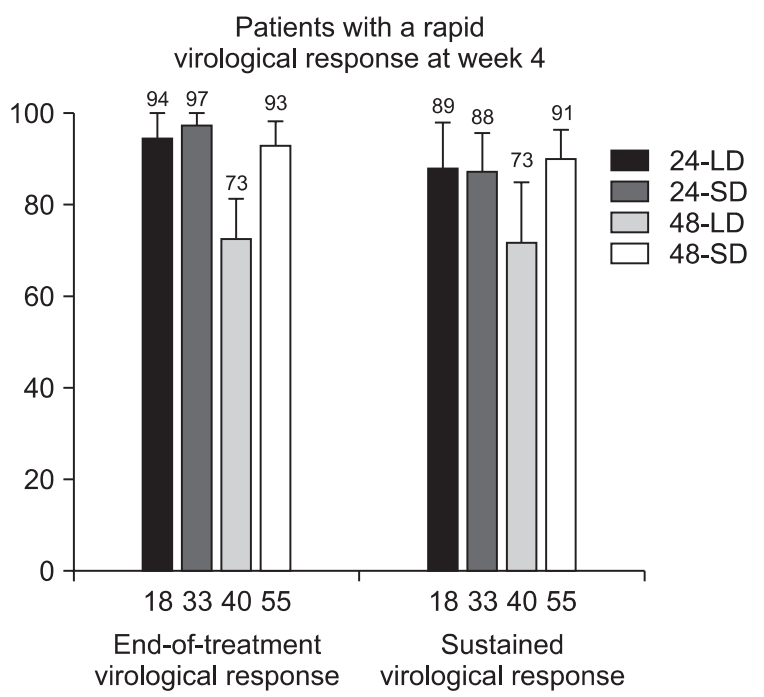

Fig. 8. End-of-treatment and sustained virological responses in patients with a rapid virological response (undetectable HCV RNA) at week 4. The number of patients in each group is presented at the base of each bar (Adapted from Jensen DM, et al. Hepatology 2006;43:954-960). ${ }^{88}$

$\mathrm{LD}$, low dose; SD, standard dose. 
and ribavirin, or even peginterferon monotherapy. ${ }^{80,88}$ Shortening the duration of therapy from 48 to 24 weeks also appeared to be effective in achieving high rates of SVR in genotype 1-infected patients showing RVR (Fig. 8). ${ }^{88}$ These observations have significant implications for peginterferon and ribavirin dosing. Because patients with RVR are highly responsive to treatment, the primary response to adverse events in these patients should include reducing the dose of peginterferon or ribavirin and not adding growth factors or other adjuvant therapies.

The later during treatment that a patient's HCV RNA becomes undetectable, the lower the likelihood of SVR. ${ }^{80}$ Patients infected with genotype 1 for whom the HCV RNA becomes undetectable between treatment weeks 4 and 12 have an SVR rate of approximately $66 \%$, but those for whom the HCV RNA becomes undetectable between weeks 12 and 24 have an SVR rate of only $45 \%$. The low SVR rate in slow responders occurs because of a higher rate of relapse. Genotype 1-infected patients with undetectable HCV RNA levels between weeks 12 and 24 have been referred to as "slow to respond," and recent studies have demonstrated that prolonging the duration of treatment in these patients from 48 to 72 weeks can significantly reduce relapse rates. $^{89,90}$ This treatment schedule would obviously enhance the likelihood of SVR. Patients infected with genotypes 2 and 3 in whom HCV RNA is not undetectable after week 4 have an SVR rate of only $49 \%,{ }^{85}$ and a recent retrospective analysis suggested that prolonging treatment in these patients could also reduce relapse.

\section{Breakthrough and relapse}

Two additional patterns of virologic response are important to recognize: breakthrough and relapse. Breakthrough is characterized by initially undetectable serum HCV RNA levels during treatment and a reappearance of serum HCV RNA despite ongoing treatment. Patients with relapse achieve and maintain undetectable HCV RNA serum levels throughout treatment but experience a reappearance of serum HCV RNA after treatment is discontinued. Common reasons for breakthrough and relapse include premature termination or temporary interruption of peginterferon or ribavirin. ${ }^{91}$

\section{Dose regimens}

The recommended starting doses for the two peginterferons aim to achieve the highest overall SVR rates. These doses were derived by balancing response and discontinuation rates. Because most patients respond to the current starting dosages of peginterferon (180 mg/wk for peginterferon alfa-2a and $1.5 \mathrm{mg} /$ $\mathrm{kg} /$ wk for peginterferon alfa-2b), it is not appropriate to initiate treatment with higher doses of these medications. The major limitation to using higher doses of interferon or peginterferon is the incidence of adverse events, which increases with increasing dose and causes patients to discontinue treatment. ${ }^{92}$ In contrast, it is reasonable to consider escalating the dose of peginterferon or to switch to high doses of daily interferon in patients with suboptimal responses who could tolerate such treatment strategies.

The treatment of chronic HCV with peginterferon and ribavirin is associated with numerous adverse events. ${ }^{81,82}$ The most common of these can be classified as systemic flu-like symptoms, psychiatric manifestations, autoimmune reactions, and hematologic toxicities. Although adverse events can be successfully managed in many cases, approximately 20\% to $40 \%$ of patients require that the dose of peginterferon or ribavirin be reduced or temporarily interrupted. In $10 \%$ to $14 \%$ of patients, adverse events are so severe that treatment must be discontinued. ${ }^{81,82}$ Higher doses of peginterferon and ribavirin have been associated with a greater incidence of adverse events. ${ }^{92-96}$

The need to alter peginterferon or ribavirin dosing in response to adverse events may have a negative impact on SVR. Two studies have clearly demonstrated that when the dose of peginterferon is reduced to less than $80 \%$ of the initial dose within the first 12 to 20 weeks of treatment, the ability of the patient to achieve EVR and to attain undetectable HCV RNA levels is significantly impaired. ${ }^{86,97}$ This is consistent with observations that achieving a virologic response depends highly on the dose of interferon $^{98}$ or peginterferon ${ }^{92-94}$ and depends far less on the ribavirin dose..$^{95,99}$ Because achieving a virologic response is the first essential milestone in achieving SVR, any reduction in the response of HCV RNA levels has a negative impact on the SVR rate.

The impacts of independent reductions in peginterferon or ribavirin doses were examined in patients with prior nonresponse to interferon (with or without ribavirin) undergoing retreatment with peginterferon and ribavirin in the Hepatitis C Antiviral Long-Term Treatment Against Cirrhosis (HALT-C) clinical trial. ${ }^{97}$ This study included more than 900 patients infected with genotype 1, making it the largest and most comprehensive analysis of dose reduction performed to date. Reducing the total cumulative dose of peginterferon to less than $80 \%$ of the initial dose led to a decline in virologic response and SVR. In contrast, reducing the dose of ribavirin had no impact on virologic response or SVR as long as patients remained on fulldose peginterferon and did not have interrupted or prematurely terminated ribavarin dosing.

Several studies have shown that the reappearance of HCV RNA after SVR is extremely rare (less than 1\%), ${ }^{100-102}$ but close follow-up is recommended. ${ }^{103}$

\section{Treatment of hepatitis $C$ in special situations}

\section{1) Acute hepatitis $C$}

The identification of acute HCV infection represents a unique window of opportunity for achieving high rates of viral clearance. An observation period of 12 weeks is recommended for patients with symptomatic hepatitis to allow for the spontaneous viral clearance that can occur at high rates in this subgroup. 
Asymptomatic patients may be treated immediately, as they are less likely to undergo spontaneous clearance. Treatment durations can vary from 24 to 48 weeks, but results from a recent analysis of 12-week treatments are encouraging, especially in those who achieve RVR. Variables associated with improved response rates include female gender, the presence of symptomatic hepatitis, younger age, non-genotype 1 infection, and RVR. Based on the current data, a management algorithm is proposed (Fig. 9) ${ }^{104}$ to guide the clinician in making treatment decisions. Of course, adherence to the prescribed therapy is extremely important in ensuring successful outcomes.

\section{2) HIV/HCV coinfection}

Because of their shared transmission routes, the prevalence of HCV and HIV coinfection ranges from $10 \%$ to $40 \%$, or even as high as $80 \%$, in highly exposed populations. ${ }^{105-107}$ Current estimates suggest that nearly 10 million individuals worldwide and 300,000 in the United States are coinfected. Because decreased mortality from opportunistic infections has been achieved with the use of highly active antiretroviral therapy (HAART), liver disease has emerged as a serious cause of morbidity and mortality among HIV-infected patients. ${ }^{108}$ HIV infection leads to increased HCV-RNA levels and faster progression of liver fibrosis. These complications consequently lead to cirrhosis, liver failure, and HCC. ${ }^{109,110}$

Several studies with pegylated IFN alfa and ribavirin have been reported. ${ }^{11-114}$ Similar to studies of patients infected with HCV alone, these trials show improved virologic response rates with the use of pegylated IFN alfa plus ribavirin compared with unmodified IFN alfa plus ribavirin. These studies also show lower response rates for patients infected with genotype 1 . In addition, the early virologic response (undetectable HCV RNA level or $>2-\log$ reduction in HCV RNA levels by week 12) also seemed to be a helpful predictor.

As with monoinfected patients, an important issue in HCV treatment is determining the appropriate time to initiate treatment in patients coinfected with HIV/HCV. When patients present with decompensated liver disease, complications of

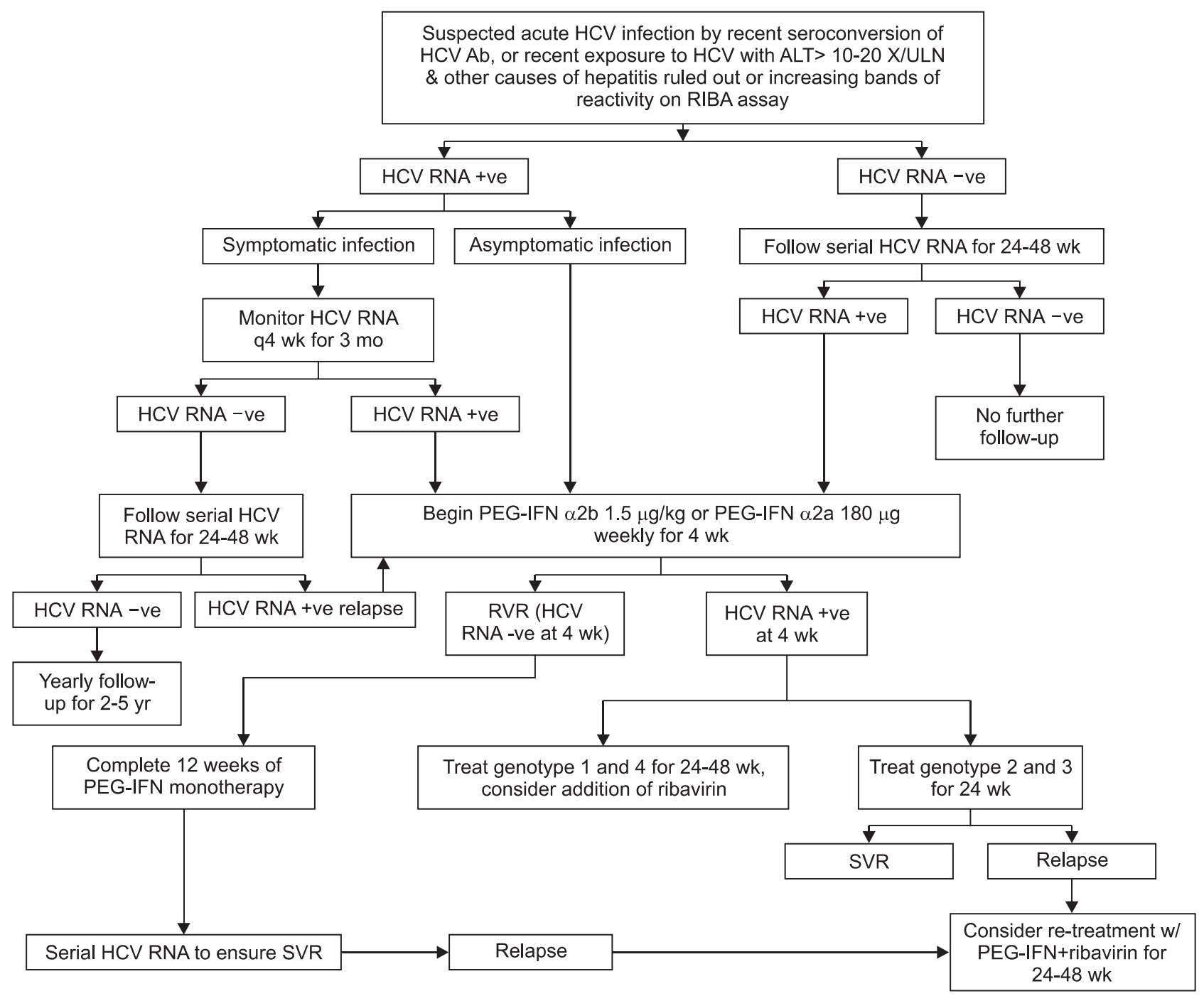

Fig. 9. Treatment algorithm for the management of acute hepatitis C (Adapted from Maheshwari A, et al. Clin Liver Dis 2010;14:169-176). ${ }^{104}$ 
HCV therapy make treatment unsafe. Effective screening and early intervention are therefore critical. Treatment must also be planned in concert with a patient's HIV physician to ensure that the patient is at a stable point in his or her HIV antiretroviral regimen. In recent $\mathrm{HIV} / \mathrm{HCV}$ studies, more than $80 \%$ of patients were receiving antiretroviral therapy, and HIV RNA was undetectable in most of these patients. In addition, mean CD4 counts were greater than $400 \times 10^{6} / \mathrm{L}$ in all trials. Considering these positive patient characteristics, these represented optimal HIV/HCV populations, but poor tolerance and adherence still emerged in these favorable patient groups. ${ }^{111-114}$

The risk-benefit analysis of HCV treatment in patients with HIV/HCV remains a matter of debate, and the safety and tolerability of therapy are therefore important concerns. HAART can be associated with hepatotoxicity ranging from elevated ALT levels to hepatic decompensation. ${ }^{115,116}$ Symptomatic mitochondrial toxicity (acute pancreatitis, lactic acidosis, or hyperlactatemia) has been reported in HIV-infected patients receiving HAART and ribavirin, and it is increased when the regimen includes didanosine. ${ }^{113}$ Chung and colleagues ${ }^{111}$ reported a clinically significant pancreatitis in only one patient but a lipase elevation in 18 subjects. Another important issue with respect to $\mathrm{HIV} / \mathrm{HCV}$ comorbidity relates to the additive side effects observed during HCV and HIV therapies. Anemia, thrombocytopenia, and neutropenia are common with peginterferon alfa and ribavirin treatments and may be exacerbated in the setting of antiretroviral therapy. Torriani et al. ${ }^{112}$ reported 37 cases (13\%) of neutropenia $\left(<500 / \mathrm{mm}^{3}\right)$ in recipients receiving peginterferon alfa-2a plus placebo and 31 cases (11\%) in recipients receiving peginterferon alfa-2a plus ribavirin; five subjects withdrew from treatment because of severe anemia. If these side effects lead to dose reductions of pegylated IFN and ribavirin, treatment with growth factors or even the selection of different antiretroviral agents may need to be considered.

\section{3) Renal failure}

Chronic HCV infection is a significant cause of morbidity and mortality in patients with end-stage renal disease (ESRD). The prevalence of anti-HCV antibodies in patients with ESRD in the United States is significantly higher than that in the general population and is estimated to be between $8 \%$ and $10 \% .{ }^{117,118}$ The natural history of HCV in patients who have ESRD, however, remains controversial. Studies of HCV infection in ESRD patients report mild to moderate disease, ALT levels that are usually within the normal range, and low proportions of patients with advanced fibrosis or cirrhosis. ${ }^{119,120}$ Mortality rates of patients with both HCV and ESRD, however, appear to be higher than rates for either ESRD or HCV alone. Stehman-Breen et al. ${ }^{121}$ reported that patients with HCV and ESRD are at an increased risk of death compared to patients with ESRD but not HCV, with an adjusted relative risk of mortality of 1.78 (95\% confidence interval [CI], 1.01 to $3.14 ; \mathrm{p}=0.045)$. A prospective cohort study followed 1,470 Japanese patients receiving hemodialysis for 6 years. ${ }^{122}$ The mortality rate was higher in patients with HCV infection than in those without HCV infection (33.0\% vs 23.2\%, $\mathrm{p}<0.01)$. HCC and cirrhosis were more frequent in patients with HCV infection.

Because of the relatively high rate of comorbidity between these two diseases, there is significant a motivation to consider the treatment of patients with both ESRD and HCV infection. This impetus is heightened if kidney transplantation is being considered. HCV infection is associated with decreased survival of the patient and the graft following kidney transplantation. ${ }^{123,124}$ Fabrizi et al. ${ }^{125}$ examined the impact of the development of posttransplantation diabetes mellitus on patient and graft survival following kidney transplantation. In a systematic review of 10 studies, they found an incidence of posttransplantation diabetes mellitus of between $7.9 \%$ and $50 \%$. They also reported that this complication was more common in patients with HCV infections (odds ratio, 3.97; 95\% CI, 1.83 to 8.61). ${ }^{125}$ Initial studies of HCV following kidney transplantation revealed that unmodified IFN alfa monotherapy improved ALT levels and led to a loss of HCV RNA but no predictable SVR. ${ }^{126-128}$ Acute cellular rejection, renal failure, and even graft loss were increased in patients treated with IFN alfa, leading to concerns regarding $\mathrm{HCV}$ treatment following kidney transplantation. As a result, recent attention has focused on treatment prior to kidney transplantation.

Many studies have been published on the use of IFN therapy for the treatment of HCV infection in patients with ESRD. Russo et al. ${ }^{129}$ conducted a systematic review of literature published between 1986 and 2001 and included data from 11 studies. In 213 patients treated with unmodified IFN alfa, SVR was 33\% overall (95\% CI, 21\% to 51\%) and was 26\% for patients infected with genotype 1 (95\% CI, 15\% to 37\%). Another meta-analysis by Meyers et al. ${ }^{130}$ included 17 studies. The overall SVR was $40 \%$ in patients receiving unmodified IFN alfa monotherapy. These pooled response rates with unmodified IFN alfa monotherapy are substantially higher than those seen in patients without renal disease. The most salient feature of these studies is the high rate of serious adverse events. Early discontinuation rates averaged at 26\%. Dose modification rates were high, and adverse events were severe and included pulmonary edema, cerebral hemorrhage, cardiomyopathy, lymphoma, and acute pancreatitis. Several studies of patients with comorbid ESRD and HCV used combination therapy with unmodified IFN alfa and ribavirin. Ribavirin is cleared by the kidney and causes a doserelated, potentially severe hemolysis. ${ }^{130}$

\section{IMPACT OF TREATMENT}

Durable loss of detectable virus from the serum is observed in almost all patients who achieve SVR (i.e., >99\%). Moreover, there is no consistent evidence of residual HCV RNA in the liver 
or extrahepatic sites following SVR. ${ }^{131}$ Most studies have also demonstrated histologic improvement, with up to $62 \%$ of patients achieving normal histological results after demonstrating $\mathrm{SVR}^{132}$ and a similar percentage showing a regression of fibrosis of up to 0.8 Metavir units per year. ${ }^{133}$ In addition to histologic improvement, several studies report that patients with SVR have a reduced risk of long-term HCV complications. Evidence overwhelmingly shows that achieving SVR increases the possibility of positive outcomes, including a reduced risk of HCC and decompensation and improved survival. ${ }^{134-136}$ In addition, a recent study by Bruno shows that achievement of SVR prevents the development of esophageal varices (0\% in SVR vs 32\% in untreated subjects over 12 years of follow-up). ${ }^{134}$ These studies present a clear picture of the striking reduction in the risk of complications of liver disease following SVR.

\section{NEW TREATMENTS FOR CHRONIC HEPATITIS C}

The depth of our understanding of the HCV life cycle has significantly expanded over the previous decade and has led to multiple new anti-HCV therapies now under investigation. Initially, such oral specifically targeted antiviral therapies for hepatitis C (STAT-C) drugs will most likely be added to current PEG-RBV therapies and could lead to improved response rates and shorter therapy durations. Improved SVR rates could be achieved with new HCV-specific inhibitors that target the NS3/4A and NS5B polymerases. Recent trials reported SVR rates on the order of $61 \%$ to $68 \%$ and $67 \%$ to $75 \%$ following combination treatments of standard of care (SOC) and the protease inhibitors telaprevir (Fig. 10) ${ }^{79}$ and boceprevir, ${ }^{137}$ respectively, in patients with HCV genotype 1 infection. Future trials will need to evaluate the use of "cocktails" of oral agents to determine whether viral resistance can be minimized with HCV as it has been with HIV and HBV. Resistance could be avoided by either combining two or more specific inhibitors with non-verlapping

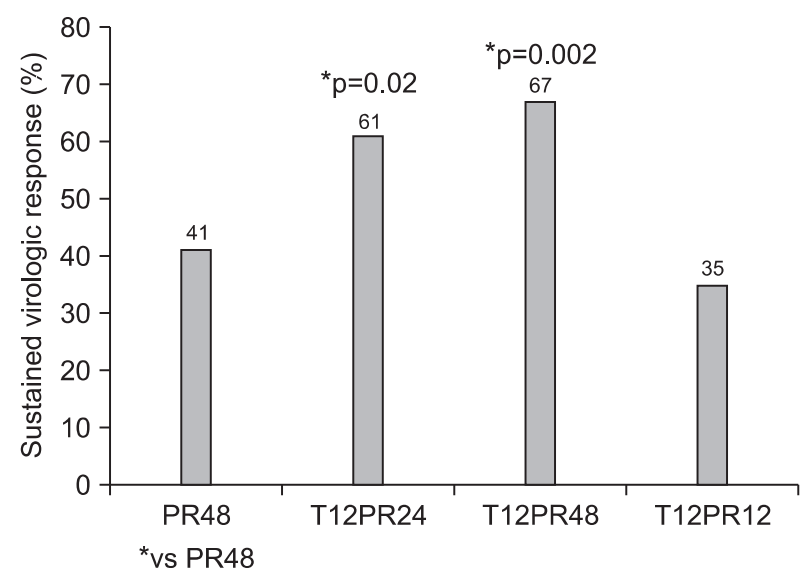

Fig. 10. Telaprevir increases sustained virologic response rates in patients with hepatitis $\mathrm{C}$ virus genotype 1 infection (Data from McHutchison JG, et al. N Engl J Med 2009;360:1827-1838). ${ }^{79}$ resistance profiles, such as protease inhibitors with nucleoside and/or non-nucleoside inhibitors, or combining HCV-specific inhibitors with non-HCV-specific inhibitors, such as cyclophilin inhibitors. Although these therapy options are not yet available, we now have the ability to adopt improved strategies to maximize response rates with available therapies and to tailor treatment durations based on individual viral kinetic responses. ${ }^{138}$

\section{SCREENING FOR HEPATOCELLULAR CARCINOMA}

The association of chronic hepatitis $\mathrm{C}$ with the development of hepatocellular carcinoma (HCC) is well documented. Most studies describing this association are retrospective case-control studies, retrospective cohort studies, or prospective cohort studies. Studies in Italy have described the incidence of hepatitis $\mathrm{C}$ cirrhosis to be 3.7 in 100,000 per year, ${ }^{139}$ the relative risk of HCC in patients positive for anti-HCV antibodies to be 21.3 compared with controls, ${ }^{140}$ and the odds ratio of developing HCC if positive for anti-HCV to be $69 .{ }^{140}$ In two studies, 71\% of HCC patients were positive for the anti-HCV. ${ }^{140,141}$ A study in the United States showed a relative risk of 4.8 and an attributable risk of $47 \%$ for HCV patients to develop HCC. ${ }^{142}$ One Japanese study showed a relative risk of 53 of developing HCC if patients were anti-HCV-positive. In this study, the prevalence of anti-HCV as a risk factor for HCC was 78\%. ${ }^{143}$ Studies in Italy, France, Germany, and other countries have reached similar conclusions. ${ }^{144-146}$ A single large-scale, prospective, controlled cohort study showed that HCV infection conferred a 20-fold increased risk for the development of HCC. ${ }^{147}$ The high incidence of HCC in patients with chronic hepatitis C-related cirrhosis has led to the introduction of screening for HCC in this population. Patients with hepatitis $\mathrm{C}$ without cirrhosis are not required to undergo HCC screening. An appropriate guiding principle is that the best available screening test should be chosen and applied regularly. Combined use of AFP and ultrasonography increases detection rates. Guidelines issued by the American Association for Study of Liver Diseases ${ }^{148}$ suggest a 6- to 12-month interval. Once an abnormal screening has been identified and patients enter into enhanced follow-up, the interval between evaluations should be shorter.

\section{SUMMARY}

1) The primary goal of treatment of chronic HCV is the attainment of SVR, defined as undetectable serum HCV-RNA levels at 6 months after treatment cessation. Once SVR is achieved, improved histological and clinical benefits follow (e.g., lower rates of decompensation, hepatocellular carcinoma, and mortality).

2) The viral factors that influence the response to IFN-based therapy include genotype and viral load. The IL28B genotype, a powerful host factor in determining IFN responsiveness, will 
eventually be used to help stratify patients for treatment.

3) The evaluation of on-treatment viral response allows for individualized treatment durations. Patients who demonstrate RVR are particularly sensitive to treatment. Shortening the duration of the therapy from 48 to only 24 weeks also seems to be effective in achieving high rates of SVR in genotype 1-infected patients who demonstrate RVR. Patients without EVR (a null response) should cease treatment because they have little chance of achieving SVR.

4) Improved rates of SVR can be achieved with new HCVspecific inhibitors against the NS3/4A and NS5B polymerases. An expanded understanding of the host proteins that enable HCV replication will allow for the identification of additional targets, eventually permitting the design of IFN-sparing regimens.

\section{FUTURE DIRECTIONS}

The addition of a protease inhibitor to a backbone of PEG/ ribavirin will emerge as the new standard of care for treatmentnaïve patients with genotype $1 \mathrm{HCV}$ or for patients with prior non-response or relapse to PEG/ribavirin treatment. Two directacting antivirals (DAAs) (a protease inhibitor and a nucleoside polymerase inhibitor) could be combined for successful, shortterm treatments. It is not unreasonable to expect that sufficient agents will be available to permit such a combination within the next 5 to 10 years. We can anticipate the introduction of strategies that add a second agent to the PEG/ribavirin/protease inhibitor backbone, particularly in difficult-to-treat patients, although the limits of tolerability are clearly being tested. Finally, the use of genetic testing for SNPs in the IL28B gene, which has been shown to have a powerful predictive value for SVR in patients treated with PEG/ribavirin, will also likely influence treatment decisions. Genotype information will potentially permit abbreviated courses of therapy in those with a favorable genotype or will indicate a deferment of IFN-based therapy for those with the unfavorable IL28B genotype. The predictive power of IL28B testing, however, will require reconfiguration in the wake of new DAA-based therapy. ${ }^{149}$

\section{ACKNOWLEDGEMENTS}

There are no conflicts to disclose for the authors.

\section{REFERENCES}

1. Alter MJ, Kruszon-Moran D, Nainan OV, et al. The prevalence of hepatitis C virus infection in the United States, 1988 through 1994. N Engl J Med 1999;341:556-562.

2. Liang TJ, Rehermann B, Seeff LB, Hoofnagle JH. Pathogenesis, natural history, treatment, and prevention of hepatitis C. Ann Intern Med 2000;132:296-305.
3. Cerny A, Chisari FV. Pathogenesis of chronic hepatitis C: immunological features of hepatic injury and viral persistence. Hepatology 1999;30:595-601.

4. Davis GL. Combination treatment with interferon and ribavirin for chronic hepatitis C. Clin Liver Dis 1999;3:811-826.

5. Centers for Disease Control and Prevention. Recommendations for prevention and control of hepatitis C virus (HCV) infection and HCV-related chronic disease. MMWR Recomm Rep 1998;47(RR19):1-39.

6. Alter MJ. Epidemiology of hepatitis C virus infection. World J Gastroenterol 2007;13:2436-2441.

7. Perz JF, Armstrong GL, Farrington LA, Hutin YJ, Bell BP. The contributions of hepatitis B virus and hepatitis $C$ virus infections to cirrhosis and primary liver cancer worldwide. J Hepatol 2006;45:529-538.

8. Garten RJ, Lai S, Zhang J, et al. Rapid transmission of hepatitis C virus among young injecting heroin users in Southern China. Int $\mathrm{J}$ Epidemiol 2004;33:182-188.

9. Higuchi M, Tanaka E, Kiyosawa K. Epidemiology and clinical aspects on hepatitis C. Jpn J Infect Dis 2002;55:69-77.

10. Yoshizawa H. Hepatocellular carcinoma associated with hepatitis $\mathrm{C}$ virus infection in Japan: projection to other countries in the foreseeable future. Oncology 2002;62 Suppl 1:8-17.

11. Iino S. Relationship between infection with hepatitis $C$ virus and hepatocellular carcinoma in Japan. Antivir Ther 1998;3(Suppl 3):143-146.

12. Fishman SL, Branch AD. The quasispecies nature and biological implications of the hepatitis C virus. Infect Genet Evol 2009;9:1158-1167.

13. Mondelli MU, Silini E. Clinical significance of hepatitis C virus genotypes. J Hepatol 1999;31 Suppl 1:65-70.

14. Global surveillance and control of hepatitis C. Report of a WHO Consultation organized in collaboration with the Viral Hepatitis Prevention Board, Antwerp, Belgium. J Viral Hepat 1999;6:35-47.

15. Nguyen MH, Keeffe EB. Chronic hepatitis C: genotypes 4 to 9. Clin Liver Dis 2005;9:411-426, vi.

16. Kamal SM, Nasser IA. Hepatitis C genotype 4: what we know and what we don’t yet know. Hepatology 2008;47:1371-1383.

17. Choo QL, Kuo G, Weiner AJ, Overby LR, Bradley DW, Houghton M. Isolation of a cDNA clone derived from a blood-borne non-A, non-B viral hepatitis genome. Science 1989;244:359-362.

18. Poynard T, Yuen MF, Ratziu V, Lai CL. Viral hepatitis C. Lancet 2003;362:2095-2100.

19. Ji H, Fraser CS, Yu Y, Leary J, Doudna JA. Coordinated assembly of human translation initiation complexes by the hepatitis $\mathrm{C}$ virus internal ribosome entry site RNA. Proc Natl Acad Sci U S A 2004;101:16990-16995.

20. Griffin S, Clarke D, McCormick C, Rowlands D, Harris M. Signal peptide cleavage and internal targeting signals direct the hepatitis C virus p7 protein to distinct intracellular membranes. J Virol 2005;79:15525-15536.

21. Kato N, Yoshida H, Ono-Nita SK, et al. Activation of intracellular 
signaling by hepatitis B and C viruses: C-viral core is the most potent signal inducer. Hepatology 2000;32:405-412.

22. Ray RB, Meyer K, Ray R. Suppression of apoptotic cell death by hepatitis C virus core protein. Virology 1996;226:176-182.

23. Zhu N, Khoshnan A, Schneider R, et al. Hepatitis C virus core protein binds to the cytoplasmic domain of tumor necrosis factor (TNF) receptor 1 and enhances TNF-induced apoptosis. J Virol 1998;72:3691-3697.

24. Hosui A, Ohkawa K, Ishida H, et al. Hepatitis C virus core protein differently regulates the JAK-STAT signaling pathway under interleukin-6 and interferon-gamma stimuli. J Biol Chem 2003;278:28562-28571.

25. Miller K, McArdle S, Gale MJ Jr, et al. Effects of the hepatitis C virus core protein on innate cellular defense pathways. J Interferon Cytokine Res 2004;24:391-402.

26. Shimotohno K, Watashi K, Tsuchihara K, Fukuda K, Marusawa H, Hijikata M. Hepatitis C virus and its roles in cell proliferation. J Gastroenterol 2002;37 Suppl 13:50-54.

27. Kamegaya Y, Hiasa Y, Zukerberg L, et al. Hepatitis C virus acts as a tumor accelerator by blocking apoptosis in a mouse model of hepatocarcinogenesis. Hepatology 2005;41:660-667.

28. Moriya K, Yotsuyanagi H, Shintani Y, et al. Hepatitis C virus core protein induces hepatic steatosis in transgenic mice. J Gen Virol 1997;78(Pt 7):1527-1531.

29. Abrignani S, Rosa D. Perspectives for a hepatitis C virus vaccine. Clin Diagn Virol 1998;10:181-185.

30. Qiao M, Murata K, Davis AR, Jeong SH, Liang TJ. Hepatitis C virus-like particles combined with novel adjuvant systems enhance virus-specific immune responses. Hepatology 2003;37:52-59.

31. Baumert TF, Ito S, Wong DT, Liang TJ. Hepatitis C virus structural proteins assemble into viruslike particles in insect cells. J Virol 1998;72:3827-3836.

32. Lechmann M, Murata K, Satoi J, Vergalla J, Baumert TF, Liang TJ. Hepatitis C virus-like particles induce virus-specific humoral and cellular immune responses in mice. Hepatology 2001;34:417-423.

33. Taylor DR, Shi ST, Romano PR, Barber GN, Lai MM. Inhibition of the interferon-inducible protein kinase PKR by HCV E2 protein. Science 1999;285:107-110.

34. Sakai A, Claire MS, Faulk K, et al. The p7 polypeptide of hepatitis $\mathrm{C}$ virus is critical for infectivity and contains functionally important genotype-specific sequences. Proc Natl Acad Sci U S A 2003;100:11646-11651.

35. Franck N, Le Seyec J, Guguen-Guillouzo C, Erdtmann L. Hepatitis C virus NS2 protein is phosphorylated by the protein kinase CK2 and targeted for degradation to the proteasome. J Virol 2005;79:2700-2708.

36. Prikhod'ko EA, Prikhod'ko GG, Siegel RM, Thompson P, Major ME, Cohen JI. The NS3 protein of hepatitis C virus induces caspase-8-mediated apoptosis independent of its protease or helicase activities. Virology 2004;329:53-67.

37. Breiman A, Grandvaux N, Lin R, et al. Inhibition of RIG-I-dependent signaling to the interferon pathway during hepatitis $C$ virus expression and restoration of signaling by IKKepsilon. J Virol 2005;79:3969-3978.

38. Loo YM, Owen DM, Li K, et al. Viral and therapeutic control of IFN-beta promoter stimulator 1 during hepatitis $\mathrm{C}$ virus infection. Proc Natl Acad Sci U S A 2006;103:6001-6006.

39. Tellinghuisen TL, Marcotrigiano J, Gorbalenya AE, Rice CM. The NS5A protein of hepatitis C virus is a zinc metalloprotein. J Biol Chem 2004;279:48576-48587.

40. Brass V, Bieck E, Montserret R, et al. An amino-terminal amphipathic alpha-helix mediates membrane association of the hepatitis $C$ virus nonstructural protein 5A. J Biol Chem 2002;277:8130-8139.

41. Moradpour D, Brass V, Penin F. Function follows form: the structure of the N-terminal domain of HCV NS5A. Hepatology 2005;42:732-735.

42. Tanji Y, Kaneko T, Satoh S, Shimotohno K. Phosphorylation of hepatitis C virus-encoded nonstructural protein NS5A. J Virol 1995;69:3980-3986.

43. Reed $\mathrm{KE}, \mathrm{Xu}$ J, Rice CM. Phosphorylation of the hepatitis $\mathrm{C}$ virus NS5A protein in vitro and in vivo: properties of the NS5A-associated kinase. J Virol 1997;71:7187-7197.

44. Ide Y, Tanimoto A, Sasaguri Y, Padmanabhan R. Hepatitis C virus NS5A protein is phosphorylated in vitro by a stably bound protein kinase from HeLa cells and by cAMP-dependent protein kinase Aalpha catalytic subunit. Gene 1997;201:151-158.

45. Appel N, Pietschmann T, Bartenschlager R. Mutational analysis of hepatitis $\mathrm{C}$ virus nonstructural protein 5A: potential role of differential phosphorylation in RNA replication and identification of a genetically flexible domain. J Virol 2005;79:3187-3194.

46. Huang Y, Chen XC, Konduri M, et al. Mechanistic link between the anti-HCV effect of interferon gamma and control of viral replication by a Ras-MAPK signaling cascade. Hepatology 2006;43:81-90.

47. Macdonald A, Harris M. Hepatitis C virus NS5A: tales of a promiscuous protein. J Gen Virol 2004;85(Pt 9):2485-2502.

48. Penin F, Dubuisson J, Rey FA, Moradpour D, Pawlotsky JM. Structural biology of hepatitis C virus. Hepatology 2004;39:5-19.

49. Lesburg CA, Cable MB, Ferrari E, Hong Z, Mannarino AF, Weber PC. Crystal structure of the RNA-dependent RNA polymerase from hepatitis C virus reveals a fully encircled active site. Nat Struct Biol 1999;6:937-943.

50. Biswal BK, Cherney MM, Wang M, et al. Crystal structures of the RNA-dependent RNA polymerase genotype $2 \mathrm{a}$ of hepatitis $\mathrm{C}$ virus reveal two conformations and suggest mechanisms of inhibition by non-nucleoside inhibitors. J Biol Chem 2005;280:18202-18210.

51. Domitrovich AM, Diebel KW, Ali N, Sarker S, Siddiqui A. Role of La autoantigen and polypyrimidine tract-binding protein in HCV replication. Virology 2005;335:72-86.

52. Luo G, Hamatake RK, Mathis DM, et al. De novo initiation of RNA synthesis by the RNA-dependent RNA polymerase (NS5B) of hepatitis C virus. J Virol 2000;74:851-863.

53. Ishii $\mathrm{N}$, Watashi K, Hishiki $\mathrm{T}$, et al. Diverse effects of cyclosporine on hepatitis C virus strain replication. J Virol 2006;80:4510-4520.

54. Pileri P, Uematsu Y, Campagnoli S, et al. Binding of hepatitis C 
virus to CD81. Science 1998;282:938-941.

55. Flint M, McKeating JA. The role of the hepatitis C virus glycoproteins in infection. Rev Med Virol 2000;10:101-117.

56. Meola A, Sbardellati A, Bruni Ercole B, et al. Binding of hepatitis C virus E2 glycoprotein to CD81 does not correlate with species permissiveness to infection. J Virol 2000;74:5933-5938.

57. Masciopinto F, Freer G, Burgio VL, et al. Expression of human CD81 in transgenic mice does not confer susceptibility to hepatitis C virus infection. Virology 2002;304:187-196.

58. Cormier EG, Tsamis F, Kajumo F, Durso RJ, Gardner JP, Dragic T. CD81 is an entry coreceptor for hepatitis C virus. Proc Natl Acad Sci U S A 2004;101:7270-7274.

59. Flint M, Thomas JM, Maidens CM, et al. Functional analysis of cell surface-expressed hepatitis C virus E2 glycoprotein. J Virol 1999;73:6782-6790.

60. Germi R, Crance JM, Garin D, et al. Cellular glycosaminoglycans and low density lipoprotein receptor are involved in hepatitis C virus adsorption. J Med Virol 2002;68:206-215.

61. Bartosch B, Vitelli A, Granier C, et al. Cell entry of hepatitis C virus requires a set of co-receptors that include the $\mathrm{CD} 81$ tetraspanin and the SR-B1 scavenger receptor. J Biol Chem 2003;278:4162441630.

62. Evans MJ, von Hahn T, Tscherne DM, et al. Claudin-1 is a hepatitis $C$ virus co-receptor required for a late step in entry. Nature 2007;446:801-805.

63. Ploss A, Evans MJ, Gaysinskaya VA, et al. Human occludin is a hepatitis $\mathrm{C}$ virus entry factor required for infection of mouse cells. Nature 2009;457:882-886.

64. Rodríguez-Iñigo E, Bartolomé J, de Lucas S, et al. Histological damage in chronic hepatitis $\mathrm{C}$ is not related to the extent of infection in the liver. Am J Pathol 1999;154:1877-1881.

65. Rehermann B, Chisari FV. Cell mediated immune response to the hepatitis C virus. Curr Top Microbiol Immunol 2000;242:299-325.

66. Zhou S, Terrault NA, Ferrell L, et al. Severity of liver disease in liver transplantation recipients with hepatitis $\mathrm{C}$ virus infection: relationship to genotype and level of viremia. Hepatology 1996;24:1041-1046.

67. Puoti C, Stati T, Magrini A. Serum HCV RNA titer does not predict the severity of liver damage in HCV carriers with normal aminotransferase levels. Liver 1999;19:104-109.

68. Romeo R, Colombo M, Rumi M, et al. Lack of association between type of hepatitis $\mathrm{C}$ virus, serum load and severity of liver disease. $\mathrm{J}$ Viral Hepat 1996;3:183-190.

69. Bowen DG, Walker CM. Adaptive immune responses in acute and chronic hepatitis C virus infection. Nature 2005;436:946-952.

70. Gale M Jr, Foy EM. Evasion of intracellular host defence by hepatitis C virus. Nature 2005;436:939-945.

71. Iwasaki A, Medzhitov R. Toll-like receptor control of the adaptive immune responses. Nat Immunol 2004;5:987-995.

72. Haller 0, Kochs G, Weber F. The interferon response circuit: induction and suppression by pathogenic viruses. Virology 2006;344:119-130.
73. Malmgaard L. Induction and regulation of IFNs during viral infections. J Interferon Cytokine Res 2004;24:439-454.

74. Zeuzem S, Fried MW, Reddy KR, et al. Improving the clinical relevance of pretreatment viral load as a predictor of sustained virological response (SVR) in patients infected with Hepatitis C genotype 1 treated with peginterferon ALFA-2A (40KD) (PEGASYS ${ }^{\circledR}$ ) plus ribavirin (COPEGUS ${ }^{\circledR}$ ) [abstract]. Hepatology 2006;44(Suppl 1):A267.

75. Romero-Gómez M, Del Mar Viloria M, Andrade RJ, et al. Insulin resistance impairs sustained response rate to peginterferon plus ribavirin in chronic hepatitis C patients. Gastroenterology 2005;128:636-641.

76. Ge D, Fellay J, Thompson AJ, et al. Genetic variation in IL28B predicts hepatitis $\mathrm{C}$ treatment-induced viral clearance. Nature 2009;461:399-401.

77. Thompson AJ, Muir AJ, Sulkowski MS, et al. Interleukin-28B polymorphism improves viral kinetics and is the strongest pretreatment predictor of sustained virologic response in genotype 1 hepatitis C virus. Gastroenterology 2010;139:120-129.e18.

78. Darling JM, Fried MW. Optimizing treatment regimens in hepatitis C. Clin Liver Dis 2006;10:835-850.

79. McHutchison JG, Everson GT, Gordon SC, et al. Telaprevir with peginterferon and ribavirin for chronic HCV genotype 1 infection. N Engl J Med 2009;360:1827-1838.

80. Ferenci P, Fried MW, Shiffman ML, et al. Predicting sustained virological responses in chronic hepatitis $\mathrm{C}$ patients treated with peginterferon alfa-2a (40 KD)/ribavirin. J Hepatol 2005;43:425433.

81. Fried MW, Shiffman ML, Reddy KR, et al. Peginterferon alfa-2a plus ribavirin for chronic hepatitis $\mathrm{C}$ virus infection. N Engl J Med 2002;347:975-982.

82. Manns MP, McHutchison JG, Gordon SC, et al. Peginterferon alfa2b plus ribavirin compared with interferon alfa-2b plus ribavirin for initial treatment of chronic hepatitis C: a randomised trial. Lancet 2001;358:958-965.

83. Lindsay KL. Introduction to therapy of hepatitis C. Hepatology 2002;36(5 Suppl 1):S114-S120.

84. Davis GL. Monitoring of viral levels during therapy of hepatitis C. Hepatology 2002;36(5 Suppl 1):S145-S151.

85. Shiffman ML, Suter F, Bacon BR, et al. Peginterferon alfa-2a and ribavirin for 16 or 24 weeks in HCV genotype 2 or 3. N Engl J Med 2007;357:124-134.

86. Davis GL, Wong JB, McHutchison JG, Manns MP, Harvey J, Albrecht J. Early virologic response to treatment with peginterferon alfa-2b plus ribavirin in patients with chronic hepatitis C. Hepatology 2003;38:645-652.

87. Sethi A, Shiffman ML. Approach to the management of patients with chronic hepatitis $\mathrm{C}$ who failed to achieve sustained virologic response. Clin Liver Dis 2005;9:453-471, vii-viii.

88. Jensen DM, Morgan TR, Marcellin P, et al. Early identification of HCV genotype 1 patients responding to 24 weeks peginterferon alpha-2a (40 kd)/ribavirin therapy. Hepatology 2006;43:954-960. 
89. Berg T, von Wagner M, Nasser S, et al. Extended treatment duration for hepatitis $C$ virus type 1: comparing 48 versus 72 weeks of peginterferon-alfa-2a plus ribavirin. Gastroenterology 2006;130:1086-1097.

90. Sánchez-Tapias JM, Diago M, Escartín P, et al. Peginterferonalfa2a plus ribavirin for 48 versus 72 weeks in patients with detectable hepatitis C virus RNA at week 4 of treatment. Gastroenterology 2006;131:451-460.

91. Bronowicki JP, Ouzan D, Asselah T, et al. Effect of ribavirin in genotype 1 patients with hepatitis $C$ responding to pegylated interferon alfa-2a plus ribavirin. Gastroenterology 2006;131:10401048.

92. Heathcote EJ, Keeffe EB, Lee SS, et al. Re-treatment of chronic hepatitis C with consensus interferon. Hepatology 1998;27:11361143.

93. Lindsay KL, Trepo C, Heintges T, et al. A randomized, doubleblind trial comparing pegylated interferon alfa- $2 \mathrm{~b}$ to interferon alfa-2b as initial treatment for chronic hepatitis C. Hepatology 2001;34:395-403.

94. Reddy KR, Wright TL, Pockros PJ, et al. Efficacy and safety of pegylated (40-kd) interferon alpha-2a compared with interferon alpha-2a in noncirrhotic patients with chronic hepatitis C. Hepatology 2001;33:433-438.

95. Shiffman ML, Salvatore J, Hubbard S, et al. Treatment of chronic hepatitis $\mathrm{C}$ virus genotype 1 with peginterferon, ribavirin, and epoetin alpha. Hepatology 2007;46:371-379.

96. Snoeck E, Wade JR, Duff F, Lamb M, Jorga K. Predicting sustained virological response and anaemia in chronic hepatitis $C$ patients treated with peginterferon alfa-2a (40KD) plus ribavirin. Br J Clin Pharmacol 2006;62:699-709.

97. Shiffman ML, Ghany MG, Morgan TR, et al. Impact of reducing peginterferon alfa-2a and ribavirin dose during retreatment in patients with chronic hepatitis C. Gastroenterology 2007;132:103112.

98. McHutchison JG, Manns M, Patel K, et al. Adherence to combination therapy enhances sustained response in genotype1-infected patients with chronic hepatitis C. Gastroenterology 2002;123:1061-1069.

99. Hadziyannis SJ, Sette H Jr, Morgan TR, et al. Peginterferonalpha2a and ribavirin combination therapy in chronic hepatitis C: a randomized study of treatment duration and ribavirin dose. Ann Intern Med 2004;140:346-355.

100. Swain MG, Lai MY, Shiffman ML, et al. A sustained virologic response is durable in patients with chronic hepatitis $\mathrm{C}$ treated with peginterferon alfa-2a and ribavirin. Gastroenterology 2010;139:1593-1601.

101. Desmond CP, Roberts SK, Dudley F, et al. Sustained virological response rates and durability of the response to interferon-based therapies in hepatitis $\mathrm{C}$ patients treated in the clinical setting. $\mathrm{J}$ Viral Hepat 2006;13:311-315.

102. Formann E, Steindl-Munda P, Hofer H, et al. Long-term followup of chronic hepatitis $\mathrm{C}$ patients with sustained virological response to various forms of interferon-based anti-viral therapy. Aliment Pharmacol Ther 2006;23:507-511.

103. Kim CH, Park BD, Lee JW, et al. Durability of a sustained virologic response in combination therapy with interferon/peginterferon and ribavirin for chronic hepatitis C. Korean J Hepatol 2009;15:70-79.

104. Maheshwari A, Thuluvath PJ. Management of acute hepatitis C. Clin Liver Dis 2010;14:169-176, $\mathrm{x}$.

105. Staples CT Jr, Rimland D, Dudas D. Hepatitis C in the HIV (human immunodeficiency virus) Atlanta V.A. (Veterans Affairs Medical Center) Cohort Study (HAVACS): the effect of coinfection on survival. Clin Infect Dis 1999;29:150-154.

106. Greub G, Ledergerber B, Battegay M, et al. Clinical progression, survival, and immune recovery during antiretroviral therapy in patients with HIV-1 and hepatitis C virus coinfection: the Swiss HIV Cohort Study. Lancet 2000;356:1800-1805.

107. Rumi MG, Colombo M, Gringeri A, Mannucci PM. High prevalence of antibody to hepatitis $\mathrm{C}$ virus in multitransfused hemophiliacs with normal transaminase levels. Ann Intern Med 1990;112:379-380.

108. Bica I, McGovern B, Dhar R, et al. Increasing mortality due to end-stage liver disease in patients with human immunodeficiency virus infection. Clin Infect Dis 2001;32:492-497.

109. Sherman KE, Rouster SD, Chung RT, Rajicic N. Hepatitis C virus prevalence among patients infected with human immunodeficiency virus: a cross-sectional analysis of the US adult AIDS Clinical Trials Group. Clin Infect Dis 2002;34:831-837.

110. Allory Y, Charlotte F, Benhamou Y, Opolon P, Le Charpentier Y, Poynard T. Impact of human immunodeficiency virus infection on the histological features of chronic hepatitis C: a case-control study. The MULTIVIRC group. Hum Pathol 2000;31:69-74.

111. Chung RT, Andersen J, Volberding P, et al. Peginterferon Alfa2a plus ribavirin versus interferon alfa-2a plus ribavirin for chronic hepatitis C in HIV-coinfected persons. N Engl J Med 2004;351:451-459.

112. Torriani FJ, Rodriguez-Torres M, Rockstroh JK, et al. Peginterferon alfa-2a plus ribavirin for chronic hepatitis $\mathrm{C}$ virus infection in HIV-infected patients. N Engl J Med 2004;351:438-450.

113. Carrat F, Bani-Sadr F, Pol S, et al. Pegylated interferon alfa-2b vs standard interferon alfa-2b, plus ribavirin, for chronic hepatitis C in HIV-infected patients: a randomized controlled trial. JAMA 2004;292:2839-2848.

114. Laguno M, Murillas J, Blanco JL, et al. Peginterferon alfa-2b plus ribavirin compared with interferon alfa-2b plus ribavirin for treatment of HIV/HCV co-infected patients. AIDS 2004;18:F27F36.

115. Vento S, Garofano T, Renzini C, Casali F, Ferraro T, Concia E. Enhancement of hepatitis $\mathrm{C}$ virus replication and liver damage in HIV-coinfected patients on antiretroviral combination therapy. AIDS 1998;12:116-117.

116. Rutschmann OT, Negro F, Hirschel B, Hadengue A, Anwar D, Perrin LH. Impact of treatment with human immunodeficiency 
virus (HIV) protease inhibitors on hepatitis C viremia in patients coinfected with HIV. J Infect Dis 1998;177:783-785.

117. Niu MT, Coleman PJ, Alter MJ. Multicenter study of hepatitis C virus infection in chronic hemodialysis patients and hemodialysis center staff members. Am J Kidney Dis 1993;22:568-573.

118. Fabrizi F, Martin P, Dixit V, et al. Quantitative assessment of HCV load in chronic hemodialysis patients: a cross-sectional survey. Nephron 1998;80:428-433.

119. Sterling RK, Sanyal AJ, Luketic VA, et al. Chronic hepatitis C infection in patients with end stage renal disease: characterization of liver histology and viral load in patients awaiting renal transplantation. Am J Gastroenterol 1999;94:3576-3582.

120. Cotler SJ, Diaz G, Gundlapalli S, et al. Characteristics of hepatitis C in renal transplant candidates. J Clin Gastroenterol 2002;35:191-195.

121. Stehman-Breen CO, Emerson S, Gretch D, Johnson RJ. Risk of death among chronic dialysis patients infected with hepatitis C virus. Am J Kidney Dis 1998;32:629-634.

122. Nakayama E, Akiba T, Marumo F, Sato C. Prognosis of anti-hepatitis $\mathrm{C}$ virus antibody-positive patients on regular hemodialysis therapy. J Am Soc Nephrol 2000;11:1896-1902.

123. Mathurin P, Mouquet C, Poynard T, et al. Impact of hepatitis $\mathrm{B}$ and $\mathrm{C}$ virus on kidney transplantation outcome. Hepatology 1999;29:257-263.

124. Hanafusa T, Ichikawa Y, Yazawa K, et al. Hepatitis C virus infection in kidney transplantation and a pilot study of the effects of interferon-alpha therapy. Transplant Proc 1998;30:122-124.

125. Fabrizi F, Martin P, Dixit V, Bunnapradist S, Kanwal F, Dulai G. Post-transplant diabetes mellitus and HCV seropositive status after renal transplantation: meta-analysis of clinical studies. Am J Transplant 2005;5:2433-2440.

126. Therret E, Pol S, Legendre C, Gagnadoux MF, Cavalcanti R, Kreis $\mathrm{H}$. Low-dose recombinant leukocyte interferon-alpha treatment of hepatitis $\mathrm{C}$ viral infection in renal transplant recipients. A pilot study. Transplantation 1994;58:625-628.

127. Magnone M, Holley JL, Shapiro R, et al. Interferon-alpha-induced acute renal allograft rejection. Transplantation 1995;59:10681070.

128. Tokumoto T, Tanabe K, Ishikawa N, et al. Effect of interferon-alfa treatment in renal transplant recipients with chronic hepatitis C. Transplant Proc 1998;30:3270-3272.

129. Russo MW, Goldsweig CD, Jacobson IM, Brown RS Jr. Interferon monotherapy for dialysis patients with chronic hepatitis C: an analysis of the literature on efficacy and safety. Am J Gastroenterol 2003;98:1610-1615.

130. Meyers CM, Seeff LB, Stehman-Breen CO, Hoofnagle JH. Hepatitis C and renal disease: an update. Am J Kidney Dis 2003;42:631657.

131. Maylin S, Martinot-Peignoux M, Moucari R, et al. Eradication of hepatitis $\mathrm{C}$ virus in patients successfully treated for chronic hepatitis C. Gastroenterology 2008;135:821-829.

132. Marcellin P, Boyer N, Gervais A, et al. Long-term histologic improvement and loss of detectable intrahepatic HCV RNA in patients with chronic hepatitis $C$ and sustained response to interferon-alpha therapy. Ann Intern Med 1997;127:875-881.

133. Abdelmalek MF, Firpi RJ, Soldevila-Pico C, et al. Sustained viral response to interferon and ribavirin in liver transplant recipients with recurrent hepatitis C. Liver Transpl 2004;10:199-207.

134. Bruno S, Crosignani A, Facciotto C, et al. Sustained virologic response prevents the development of esophageal varices in compensated, Child-Pugh class A hepatitis C virus-induced cirrhosis: a 12-year prospective follow-up study. Hepatology 2010;51:2069-2076.

135. Veldt BJ, Heathcote EJ, Wedemeyer H, et al. Sustained virologic response and clinical outcomes in patients with chronic hepatitis C and advanced fibrosis. Ann Intern Med 2007;147:677-684.

136. Bruno S, Stroffolini T, Colombo M, Sustained virological response to interferon-alpha is associated with improved outcome in HCVrelated cirrhosis: a retrospective study. Hepatology 2007;45:579587.

137. Kwo P, Lawitz E, McCone J, et al. HCV SPRINT-1 final results: SVR 24 from a phase 2 study of boceprevir plus pegintron ${ }^{\mathrm{TM}}$ (peginterferon ALFA-2B)/ribavirin in treatment-naive subjects with genotype-1 chronic hepatitis C. J Hepatol 2009;50(Suppl 1):S4.

138. Jang JY, Chung RT. New treatments for chronic hepatitis C. Korean J Hepatol 2010;16:263-277.

139. Chiaramonte M, Stroffolini T, Vian A, et al. Rate of incidence of hepatocellular carcinoma in patients with compensated viral cirrhosis. Cancer 1999;85:2132-2137.

140. Simonetti RG, Cammà C, Fiorello F, et al. Hepatitis C virus infection as a risk factor for hepatocellular carcinoma in patients with cirrhosis: a case-control study. Ann Intern Med 1992;116:97-102.

141. Stroffolini T, Andreone P, Andriulli A, et al. Characteristics of hepatocellular carcinoma in Italy. J Hepatol 1998;29:944-952.

142. Yu MC, Tong MJ, Coursaget P, Ross RK, Govindarajan S, Henderson BE. Prevalence of hepatitis B and C viral markers in black and white patients with hepatocellular carcinoma in the United States. J Natl Cancer Inst 1990;82:1038-1041.

143. Tanaka K, Ikematsu H, Hirohata T, Kashiwagi S. Hepatitis C virus infection and risk of hepatocellular carcinoma among Japanese: possible role of type 1b (II) infection. J Natl Cancer Inst 1996;88:742-746.

144. Fattovich G, Giustina G, Degos F, et al. Morbidity and mortality in compensated cirrhosis type C: a retrospective follow-up study of 384 patients. Gastroenterology 1997;112:463-472.

145. Niederau C, Lange S, Heintges T, et al. Prognosis of chronic hepatitis C: results of a large, prospective cohort study. Hepatology 1998;28:1687-1695.

146. Degos F, Christidis C, Ganne-Carrie N, et al. Hepatitis C virus related cirrhosis: time to occurrence of hepatocellular carcinoma and death. Gut 2000;47:131-136.

147. Sun CA, Wu DM, Lin CC, et al. Incidence and cofactors of hepatitis C virus-related hepatocellular carcinoma: a prospective study of 12,008 men in Taiwan. Am J Epidemiol 2003;157:674-682. 
132 Gut and Liver, Vol. 5, No. 2, June 2011

148. Bruix J, Sherman M; Practice Guidelines Committee, American Association for the Study of Liver Diseases. Management of hepatocellular carcinoma. Hepatology 2005;42:1208-1236.

149. Chung RT. AASLD 2010 postgraduate course: future therapy of hepatitis C [Internet]. Alexandria: American Association for the Study of Liver Diseases; c2011 [cited 2011 Apr 20]. Available from: http://74.43.177.57/courses/2010/pg/chung/player.html. 